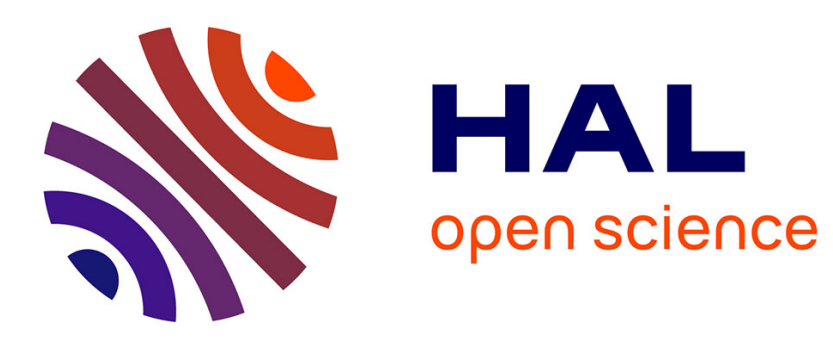

\title{
ANOMALOUS TEMPERATURE DEPENDENCE OF A LO MODE IN LiKSO4
}

M. Bansal, S. Deb, Arnaud Roy, V. Sahni

\section{To cite this version:}

M. Bansal, S. Deb, Arnaud Roy, V. Sahni. ANOMALOUS TEMPERATURE DEPENDENCE OF A LO MODE IN LiKSO4. Journal de Physique Colloques, 1981, 42 (C6), pp.C6-902-C6-904. 10.1051/jphyscol:19816268. jpa-00221360

\section{HAL Id: jpa-00221360 https://hal.science/jpa-00221360}

Submitted on 1 Jan 1981

HAL is a multi-disciplinary open access archive for the deposit and dissemination of scientific research documents, whether they are published or not. The documents may come from teaching and research institutions in France or abroad, or from public or private research centers.
L'archive ouverte pluridisciplinaire HAL, est destinée au dépôt et à la diffusion de documents scientifiques de niveau recherche, publiés ou non, émanant des établissements d'enseignement et de recherche français ou étrangers, des laboratoires publics ou privés. 
JOURNAL DE PHYSIQUE

Colzoque C6, supplément au $n^{\circ} 12$, Tome 42 , décembre 1981

page $\quad$ 66-902

ANOMALOUS TEMPERATURE DEPENDENCE OF A LO MODE IN LiKSO 4

M.L. Bansa1, S.K. Deb, A.P. Roy and V.C. Sahni

Muclear Physics Division, Bhabha Atomic Research Centre, Trombay, Bombay 400 085 , India

\begin{abstract}
Abatract.- Raman ecattering meavuremente for $\mathrm{L}_{15 \mathrm{O}_{4}}$ over the temperature range $200 \mathrm{~K}$ to $725 \mathrm{~K}$ are reported. The reaults corroborate the occurrence of a phase transition at $700 \mathrm{~K}$ and also exhibit two unusual lattice dynamical features viz an inverted IO-TO splitting and an increase in the frequency of a normal mode with rise in temperature. A phenomenologi al explanation for the ee features io given.
\end{abstract}

1. Introduction.- We had recently ${ }^{2}$ established a subtle firet order low temperature phase transition in Iikso $4\left(c_{6}^{6} \rightarrow c_{3 V}^{4}\right.$ ) (at $201 \mathrm{~K}$ ) us ing Raman scattering measurements and we have extended our measurements to high temperature region since additional phase tranaition ( $700 \mathrm{~K})$ had been proposed for this crystal in the literature ${ }^{2}$.

In extending our measurements upto $725 \mathrm{~K}$ while we have found evidence that a phase transition does occur around $700 \mathrm{~K}$, in addition, we have found two interest ing features of vibrational modes in the temperature range between the transition pointa (cryatal symetry $c_{6}^{6}$ ). These features are: (I) the Lo frequenoy of a $\nu_{2}$ mode of $\mathrm{sO}_{4}$ appears below its to counterpart and (11) the frequency of this Io mode increases with the rise in temperature. Since these are somewhat unusual features we propose to discuse these in greater detall here and except for a brief mention, omit the discussion of the ohanges pertalning to high temperature phase traneition.

In eection 2 we describe experimental detailo and present the epectra. Diecuesion of the results and a posible explanation for the IO-TO frequency inversion and anomalous temperature dependence of the $s_{1}(I O) \nu_{2}$ mode are given in gection 3 .

2. Experimental details.- Polarized Raman Spectra were recorded using a home made $40 \mathrm{mfll}$ He-Cd laser and a grating double monochromator 3 with spetral bandpase of $3.5 \mathrm{~cm}^{-1}$.

For high temperature studies, we used a cell, wherein the sample is mounted mechanically and 1 ts three faces are in contact with copper to ensure uniformity of temperature. The temperature was 


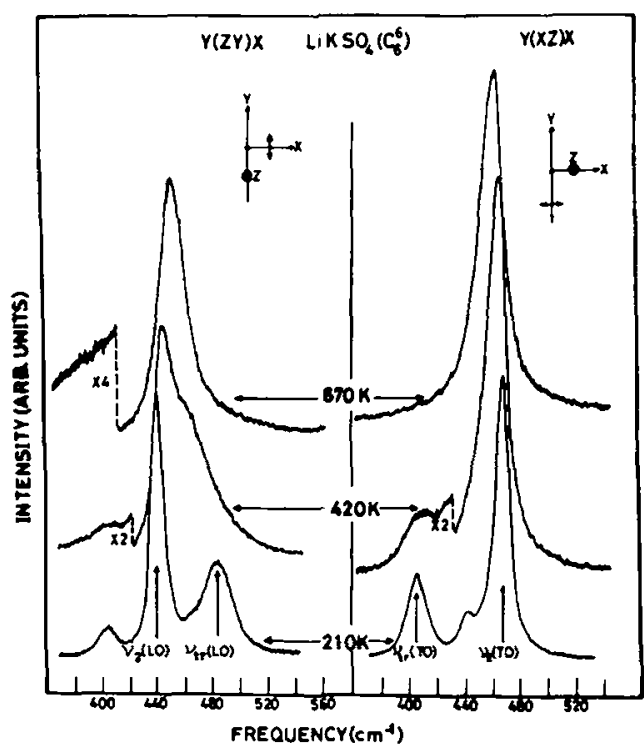

Fig.l Raman epectra at different temperaturee for two orlentations.

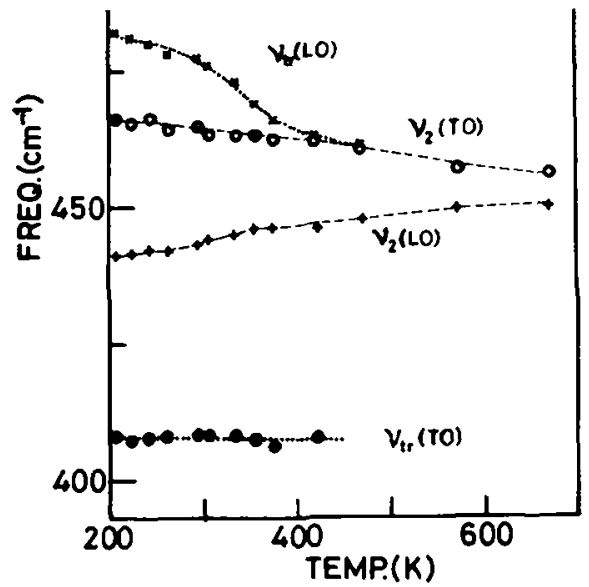

Plg.2 Frequency variation of modee of Fig. I with temperature.

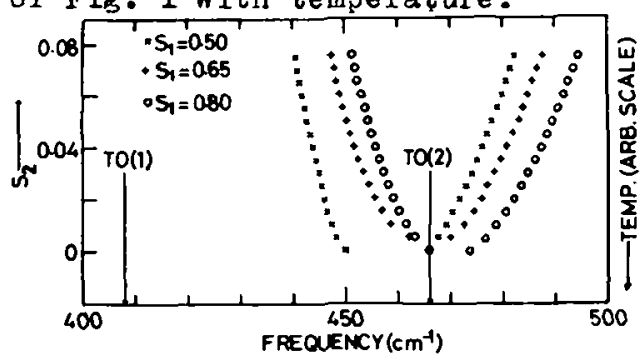

Pig.3 Dependence of to frequencies on $S_{1} \& S_{2}$. Input To frequencieg are also ehown. monitored using a opper constant thermocouple and a proportional temperature controller was used to maintain it conatant within $\pm 0.5^{\circ} \mathrm{C}$. The reported temperature values refer to the temperature of the copper block; the eample temperature is somewhat lower (by $\sim 10 \mathrm{~K}$ at $600 \mathrm{~K}$ ).

3. Regults and Discuesion:- P1g. 1 shows the temperature dependence $(210 K-675 K)$ of $Y(Z Y) X$ and $Y(X Z) X$ epectra over the frequency range $400 \mathrm{~cm}^{-1}-520 \mathrm{~cm}^{-1}$. $\nu_{t_{r}}$ and $\nu_{2}$ label modes 1nvolving predominantly Ii tranelation and $\mathrm{SO}_{4}$ internal vibration respe ot $1 v e l y$. Further as is often the case with If salts, the Ionic conductivity increases considerably with the riae in temperature. So the former mode oan be expected to broaden more rapidly with increaging temperature. The asaignme at of IO modes in Fig.I is based on this premise and is different from earlier assignmenta. $1 \mathrm{~g} .2$ showe plot of frequencles versus temperature. Note that for the $\nu_{2}$ mode IO-TO eplitting is Inverted. The behaviour can be underitood using a picture of two nearby oscillators where one of them carried a much larger dipole noment. In approximate expression for the dielectric function, valid in thio frequency range is

$$
\epsilon_{1}(\nu)=\text { Const }+\frac{s_{1} \nu_{t+}^{2}(T 0)}{\nu_{t+}^{2}(r 0)-\nu^{2}}+\frac{s_{2} \nu_{2}^{2}(T 0)}{\nu_{2}^{2}(r 0)-\nu^{2}}(1)
$$

The Io frequencies obtained from the zeros of eqn.(1) for a glven set of To frequencies and osclilator 
strengthe $S_{1}$ and $S_{2}$ are given in Table 1. Hiraishi et a ${ }^{4}$ give values of $s_{1}$ and $s_{2}$ from an analyois of their room temperature IR reflection spectra. The values chosen by us at $210 \mathrm{~K}$ are close to theirs.

The most notable feature about temperature variation of various moder (FIgB. I\&2) is that both $\nu_{t y}$ (IO) and $\nu_{2}$ (IO) converge towards $\nu_{2}$ (TO) as temperature is increased; the former decreases by $17 \mathrm{~cm}^{-1}$ wherese the latter increases by $6 \mathrm{~cm}^{-1}$ over the temperature interval $210 \mathrm{~K}-420 \mathrm{~K}$. Thle behaviour can be quantitatively reproduced using eq.(1) assuming a decrease in the value of $\mathrm{s}_{2}$ from 0.065 to 0.015 (Table 1). In equ(1), the damping has been neglected and to that extent choice of the initial values of $S_{1}$ and $S_{2}$ is somewhat uncertain. A glance at Fig.3 clearly showe that for predicting the obeerved relative shifts of $\nu_{2}$ (IO) and $\nu_{t+}(I O), S_{2}$ has to decrease with increasing temperature, irrespective of the uncertainty in the initial choice of $s_{1}$ and $s_{2}$. Variation of $s_{1}$ keeping $\mathrm{S}_{2}$ fixed leads to eimultaneous increase or decrease of both $\nu_{2}(I O)$ and $\nu_{t+}$ (IO), whereas experimentally $\nu_{2}$ (IO) increases and $\nu_{t r}$ (IO) decreases with increasing temperature. At still higher temperature (> 420K) L1 modes can not be traced experimentally but $\nu_{2}$ (IO) movee progressively closer to $\nu_{2}$ (TO). Since the $\nu_{2}$ mode is IR inactive in the free ion atate, this continuous decrease in the oscillator strength implies that the $\mathrm{SO}_{4}$ distortion (from tetrahedral whe) diminishes With increasing temperature. Across $700 \mathrm{~K}$ changes in the Raman opectra occur over the entire frequency range. Further, the widtho of mogt of the modeg change abruptly acroeg the trangition point. However, as the widthe of the peaks are rather large (FWHM even as much as $40 \mathrm{~cm}^{-1}$ ) detailed examination of the transition by Raman scattering alone, seem unfeasible and other techniques may be necsary for elucidation of the traneition.

Table I: Observed and calculated lo frequencies (in $\mathrm{cm}^{-1}$ )

\begin{tabular}{|c|c|c|c|c|c|}
\hline$\underline{T}(\mathrm{~K})$ & $\mathrm{obs}_{\mathrm{B}}(\mathrm{TO})$ & $\mathrm{obs}(\mathrm{IO})$ & cal (Io & 2 & \\
\hline 210 & $\begin{array}{l}408 \\
466 \\
\end{array}$ & $\begin{array}{l}440 \\
480 \\
\end{array}$ & $\begin{array}{l}441 \\
480 \\
\end{array}$ & $\begin{array}{l}s_{1} \\
s_{2}\end{array}$ & $\begin{array}{l}=0.50 \\
=0.065\end{array}$ \\
\hline 420 & $\begin{array}{l}408 \\
462\end{array}$ & $\begin{array}{l}446 \\
463\end{array}$ & $\begin{array}{l}446 \\
466\end{array}$ & $\begin{array}{l}s_{1} \\
s_{2}\end{array}$ & $\begin{array}{l}=0.50 \\
=0.015\end{array}$ \\
\hline
\end{tabular}

References.- I. M.I. Bansal, S.K.Deb,A.P.Roy \& V.C.Sahnl, Sol. St. Commu., 36, 1047(1980).

2. D.P.Sharma, Pramana, 13, $223(1979)$, and references therein.

3. M.I.Baneal, T.R.Rao, V.C.Sahn1 \& A.P.Roy, Ind.J.Phys . 50, 199(1976).

4. J.Hiraighi, N.Taniguchi and H. Takahaehi, J. Chem. Phys. 65, 3821 (1976). 